\title{
EFFECT OF ORAL ADMINISTRATION WITH GRAPE SEEDS EXTRACT ON GROWTH PERFORMANCE, CARCASS TRAITS AND BLOOD PARAMETERS OF GROWING RABBITS
}

\author{
A.E. Abd El-Khalek ${ }^{1}$; H.K. Zaghloul ${ }^{2}$ and M. Z. A. Badawy ${ }^{1}$ \\ ${ }^{1}$ Animal Production Department, Faculty of Agriculture, Mansoura University. Mansoura, Egypt. \\ ${ }^{2}$ High Institute for Agricultural Co-Operation, Shoubra El-Khima, Egypt.
}

(Received $10 / 1 / 2017$, Accepted 28/2/2017)

\section{SUMMARY}

\begin{abstract}
$\mathrm{T}$ The current study was conducted to evaluate effect of oral grape seeds extract (GSE) at levels of 0 , 75 and $125 \mathrm{mg} / \mathrm{kg}$ LBW daily for 21 days on growth performance, carcass traits and blood parameters of growing APRI rabbits. Total of fifteen growing APRI rabbit males having live body weight (LBW) of $618.67 \mathrm{~g}$ and 8 weeks of age, were divided into three similar groups $(\mathrm{n}=5 \mathrm{in}$ each) rabbits in the $1^{\text {st }}$ group were given $3 \mathrm{ml}$ sterile distilled water (Control, G1), while in the $2^{\text {nd }}$ and $3^{\text {rd }}$ groups were given $3 \mathrm{ml}$ distilled water containing 75 (G2) or $125 \mathrm{mg} / \mathrm{kg} \mathrm{LBW}$ (G3) grape seeds extract. All rabbits were fed commercial complete feed diet and kept under the same managerial and climatic conditions. Results show that, the average final body weight, total weight gain and daily body weight gain of rabbits in G3 were significantly higher $(\mathrm{P}<0.05)(2180,1564$ and $27.93 \mathrm{~g})$ than in $\mathrm{G} 2(2013,1399$ and $24.98 \mathrm{~g})$ and control $(\mathrm{G} 1)$ (1993, 1367 and 24.41g), respectively. Average daily feed intake was significant $(\mathrm{P}<0.05)$ higher for rabbit with oral grape seeds extract at $12 \mathrm{mg}$ than for control, but no significant affected between the two levels (G2 and G3). Results showed insignificant effect of oral grape seeds extract on average feed conversion ratio (gm feed/g gain). However, there was a tendency of reduction for rabbit treated with $125 \mathrm{mg} / \mathrm{kg}$ (G3) as compared to level $75 \mathrm{mg} / \mathrm{kg}$ (G2) and control group (G1). Results showed that oral grape seeds extract were insignificantly affected in all carcass parameters, however, the tendency in carcass characteristics values (weight after slaughter, weight with abdominal, giblets, empty, head, spleen, heart and kidney) higher in rabbits treated with $125 \mathrm{mg} / \mathrm{kg}$ (G3) followed by treated with $75 \mathrm{mg} / \mathrm{kg}$ (G2) then control group (G1). Concentrations of total cholesterol (TC), triglyceride (TG) and low density lipoprotein (LDL) and AST were significantly higher $(\mathrm{P}<0.05)$ for growing rabbit in control group $(\mathrm{G} 1)$ than both treatments $(\mathrm{G} 2$ and $\mathrm{G} 3)$, while did not significant effect on concentration of total protein, albumin, globulin, A/G ratio, creatinine and activity of ALT enzyme. These findings suggest that oral of grape seeds extract with level of $125 \mathrm{mg} / \mathrm{kg}$ lead to improvement growth performance, health status and decreasing lipid contents in the body of APRI rabbits.
\end{abstract}

Keywords: Grape seeds extract, rabbits, growth performance, carcass trait, blood parameters.

\section{INTRODUCTION}

Lipid peroxidation can be minimized by supplementation of antioxidant vitamins (Puthpongsiriporn et al., 2001 and Franchini et al., 2002) or natural substances that possess antioxidant potential (Sahin et al., 2008 and Tuzcu et al., 2008).

Antioxidants play an important role in protecting cells from reactive oxygen species by reducing free radicals and preventing the peroxidation of lipids (Grashorn, 2007 and Nanari et al., 2004). Moreover, Benzie, (2003) reported that, antioxidant enzymes have the capacity to break down free-radical reactions using a chain reaction mechanism. The living organisms can synthesize some of these antioxidants, whereas others need to be provided by the diet (Strain and Benzie, 1999).

Flavonoids consist of the largest group of plant phenolics among the eight thousand naturally occurring phenolic compounds (Ruberto et al., 2007). The beneficial effects derived from phenolic compounds have been attributed to their antioxidant activity. Studies have shown that flavonoids have the capacity to act as powerful antioxidants by scavenging free radicals and terminating oxidative reactions (Gonzalez- Paramas et al., 2004; Yilmaz and Toledo, 2004; Ruberto et al., 2007). Flavonoids having multiple hydroxyl groups, also act as pro-oxidants (Heim et al., 2002; Miguel, 2010). The proposed mechanism of action for flavonoids is conversion of hydroxyl group into pro-oxidant when oxidized by 
reactive oxygen species (ROS) present in inner cell membrane and able to oxidize lipids, proteins and DNA, thus may lead to late necrosis or apoptosis of damaged cells by eliminating potential mutants (Bakkali et al., 2008). Many researchers conducted studies on medicinal plants and forages having polyphenolic compounds as an alternative strategy to treat coccidiosis. In a study on anticoccidial effect for grape seeds proanthocyanidine extract (natural polyphenolic antioxidant) against $E$. tenella infection, the significant reduction in mortality and improved bird performance was observed (Wang et al., 2008). Proanthocyanidins are multifunction and powerful antioxidants having free radical scavenging activity (Cos et al., 2003). Furthermore, proanthocyanidins are potent inhibitor of the proinflammatory cytokine and chemokine responses induced by lipopolysaccharides (Bodet et al., 2006). Xanthohumol (XN), a prenylated flavonoid, obtained from the hops plant, has been reported to have anticoccidial activity against different Eimeria species in chickens (Allen, 2007).

The present study was carried out to study the effect of oral three levels of grape seeds extract (0.0, 75 and $125 \mathrm{mg} / \mathrm{kg} \mathrm{LBW}$ ) on growth performance, carcass traits and blood parameters of growing APRI rabbit bucks.

\section{MATERIALS AND METHODS}

The experimental work was carried out in Rabbit Farm, Department of Animal Production, Faculty of Agriculture, Mansoura University, Mansoura, Egypt. During the period from August till November 2016.

\section{Animals:}

A total number of 15 APRI line rabbits males (50\% Red Baladi bucks X $50 \mathrm{~V}$ line dose) were used in this study. The rabbits aged 8 weeks and weighted in average $618.67 \mathrm{~g}$. The rabbits were divided randomly equally on 3 groups, ( $\mathrm{n}=5$ in each group). Rabbits in the $1^{\text {st }}$ group were given $3 \mathrm{ml}$ sterile distilled water (Control, G1), while in the $2^{\text {nd }}$ and $3^{\text {rd }}$ groups were given 3 ml distilled water contained 75 (G2) or $125 \mathrm{mg} / \mathrm{kg} \mathrm{LBW}$ (G3) grape seeds extract, respectively for 21 days as experimental period.

The requirement of the experimental diet and grape seeds extract for each weak were prepared according to the live body weight of rabbits weakly. The rabbits were fed ad-libitum on a commercial pelleted complete ration consist of barley, clover hay, wheat bran, yellow corn, soybean meal $44 \%$, cotton seed meal, mineral and vitamin premix. The diet contained $2.3 \%$ fat, $16.5 \%$ crude protein, $13 \%$ crude fiber, $17 \%$ ash and $2740 \mathrm{Kcal}$ digestible energy (DE) $/ \mathrm{kg}$ on dry mater basis. Chemical composition of the experimental diet presented in Table (1).

All rabbits were housed in individual galvanized wire batteries arranged in rows, and located in conventional building ventilated by electric fans. All cages of were equipped with feeders made of galvanized metal and has nipple for automatic drinking water.

\section{Experimental procedures:}

Live body weight of rabbits and feed intake were recorded weekly, then body weight gain and feed conversion ratio were calculated weekly throughout the excremental period from 8 to $16 \mathrm{wk}$. of age.

\section{Biochemical analysis:}

Blood samples were collected from three rabbits in each group at the end of treatment. The blood samples were taken from the ear vein of bucks. Blood was taken into vacotainer tubes, centrifuged at $3000 \mathrm{rpm}$ for 20 minutes to separate blood serum using serological pipettes, then serum was carefully decanted into labeled tubes and stored at $-20^{\circ} \mathrm{C}$ until analysis. Concentration of total protein (Gornall et al., 1949), albumin (Doumas et al., 1971) glucose (Trinder, 1969) Total closterol (Potman and Stroes, 1968), creatinine (Tabacco, 979), high density lipoprotein and low density lipoprotein (Friedewald et al., 1972), triglyceride (Bucolo and david,1973 ) as well as activity of aspartate (AST) and alanine (ALT) transaminases (Reitman and Frankel, 1957). However, concentration of globulin was calculated by subtracting albumin from total protein concentration. Albumin/globulin ratio $(\mathrm{A} / \mathrm{G})$ ratio was calculated.

\section{Carcass traits:}

At the end of experimental period, 3 rabbits from each group were randomly taken, fasted for 12 . hr to determine carcass characteristics according to Steven et al. (1981). 
Table (1): Ingredients and chemical composition of the experimental diet.

Item

\begin{tabular}{|c|c|}
\hline \multicolumn{2}{|l|}{ Ingredients, $\%$} \\
\hline Barely grains & 32.80 \\
\hline Clover hay & 27.41 \\
\hline Wheat bran & 17.10 \\
\hline Soybean meal (44\% CP) & 16.24 \\
\hline Molasses & 3.00 \\
\hline Di calcium phosphate & 2.00 \\
\hline Sodium Chloride $(\mathrm{NaCl})$ & 0.30 \\
\hline Vit.\& min. Mix* & 0.30 \\
\hline Lime stone & 0.40 \\
\hline DL-Methionine & 0.40 \\
\hline Anticoccidia (Diclazuril) & 0.05 \\
\hline Total & 100 \\
\hline \multicolumn{2}{|l|}{ Composition (calculated ${ }^{1}$ ) } \\
\hline $\mathrm{OM}, \%$ & 89.76 \\
\hline $\mathrm{CP}, \%$ & 17.26 \\
\hline $\mathrm{CF}, \%$ & 12.92 \\
\hline $\mathrm{EE}, \%$ & 2.16 \\
\hline NFE, $\%$ & 57.42 \\
\hline Ash, $\%$ & 10.24 \\
\hline $\mathrm{DE}, \mathrm{kcal} / \mathrm{kg}$ & 2518.7 \\
\hline Calcium, \% & 1.13 \\
\hline Total phosphorus, $\%$ & 0.80 \\
\hline Methonine, \% & 0.64 \\
\hline Lysine, \% & 0.86 \\
\hline
\end{tabular}

\section{Statistical Analysis:}

The obtained data were statistically analyzed according to one way complete design to study the effect of treatment using SAS (2004). However, the significant differences among treatment groups were tested using Duncan's Multiple Range Test (Duncan, 1955). And the statistical moles was:

$$
Y_{i j}=U+A_{i}+e_{i j}
$$

Where:

$\mathrm{Y}_{\mathrm{ij}}=$ Observed traits

$\mathrm{U}=$ Overall mean

$\mathrm{A}_{\mathrm{i}}=$ Experimental group 1-3 $(1=\mathrm{G} 1,2=\mathrm{G} 2$ and $3=\mathrm{G} 3)$

$\mathrm{e}_{\mathrm{ij}}=$ Random error

\section{RESULTS AND DISCUSSION}

\section{Growth performance:}

Live body weights (LBW) of rabbit bucks at the initial and end of treatment period are presented in Table (2). 
Abd El-Khalek et al.

Table (2): Effect of different oral grape seeds extract levels on growth performance of growing rabbits.

\begin{tabular}{lccc}
\hline \multirow{2}{*}{ Item } & $(\mathrm{G} 1)$ & \multicolumn{2}{c}{ Oral grape seeds extract level } \\
\cline { 3 - 4 } & Control & $(\mathrm{G} 2) 75 \mathrm{mg} / \mathrm{kg}$ & $(\mathrm{G} 3) 125 \mathrm{mg} / \mathrm{kg}$ \\
\hline Experimental period (day) & 56 & 56 & 56 \\
Initial body weight $(\mathrm{gm})$ & $626.0 \pm 25.02$ & $614.0 \pm 12.99$ & $616.0 \pm 21.1$ \\
Final body weight $(\mathrm{gm})$ & $1993 \pm 50.73^{\mathrm{b}}$ & $2013 \pm 46.73^{\mathrm{b}}$ & $2180 \pm 37.98^{\mathrm{a}}$ \\
Total weight gain $(\mathrm{gm})$ & $1367.0 \pm 65.83^{\mathrm{b}}$ & $1399.0 \pm 41.93^{\mathrm{b}}$ & $1564.0 \pm 23.9^{\mathrm{a}}$ \\
Daily body weight gain $(\mathrm{gm})$ & $24.41 \pm 1.18^{\mathrm{b}}$ & $24.98 \pm 0.75^{\mathrm{b}}$ & $27.93 \pm 0.43^{\mathrm{a}}$ \\
Daily feed intake $(\mathrm{gm})$ & $77.6 \pm 2.23^{\mathrm{b}}$ & $80.81 \pm 1.71^{\mathrm{ab}}$ & $83.4 \pm 0.73^{\mathrm{a}}$ \\
Feed conversion ratio & $3.18 \pm 0.19$ & $3.23 \pm 0.05$ & $2.99 \pm 0.05$ \\
(g feed/g gain) & & & \\
\hline a and b--- Means in the same row with different superscripts are significantly different $(P<0.05)$.
\end{tabular}

Analysis of variance revealed that LBW of rabbits was not affected significantly at initial of treatment, while at the end of oral grape seed extract treatment, the average final body weight, total weight gain and daily body weight gain of G3 (with level of $125 \mathrm{mg} / \mathrm{kg}$ ) were significantly higher (P>0.05) (2180, 1564 and $27.93 \mathrm{~g}$ ) than group (G2) with level of $75 \mathrm{mg} / \mathrm{kg}(2013,1399$ and $24.98 \mathrm{~g})$ and control (G1) (1993, 1367 and $24.41 \mathrm{~g}$ ), respectively (Table 2 ).

Average daily feed intake for rabbit bucks was significant affected $(\mathrm{P}<0.05)$ by oral grape seeds extract, showed higher values for rabbit bucks treated with both levels than for control, but no significant affected between the two levels (G2 and G3).

Results showed insignificant effect for oral grape seeds extract on feed conversion ratio. However, there was a tendency of reduction in rabbits treated with level $125 \mathrm{gm} / \mathrm{kg}(\mathrm{G} 3)$ as compared to level of 75 $\mathrm{gm} / \mathrm{kg}(\mathrm{G} 2)$ and control group (G1) during experimental periods.

Increasing of GSE level in the chicken diets did not change the growth performance, feed consumption and feed conversion ratio at 21 and 42 days of age compared with those fed control diet, Brenes et al. (2010)

\section{Carcass characteristics:}

Carcass characteristics at the end experimental period are presented in Table (3). The obtained results showed that oral grape seeds extract were insignificantly effected in all carcass parameters, However, the tendency in carcass characteristics values (weight after slaughter, weight with abdominal, giblets, empty, head, spleen, heart and kidney) higher in rabbit bucks treated with $125 \mathrm{gm} / \mathrm{kg}$ (G3) followed by $75 \mathrm{gm} / \mathrm{kg}$ (G2) then control group (G1). While, liver was higher in rabbit bucks in G3 followed by control group then in group $2(\mathrm{G} 2)$. But, the tendency in carcass characteristics (lung, bile, shoulder fat and abdominal fat) higher in rabbit bucks treated with $75 \mathrm{gm} / \mathrm{kg}(\mathrm{G} 2)$ followed by $125 \mathrm{gm} / \mathrm{kg}$ (G3) then control group (G1).

The graded concentrations of GSE did not affect the relative organ weights (pancreas, liver, liver fat and abdominal fat), except for spleen which was increased up to $14 \%$ at 42 days of birds age fed the highest concentrations of GSE compared with those fed control diet (Brenes et al., 2010).

Hassan, et al. (2016) reported that dietary GSE improved carcass weight, percentage of hot carcass, intestine and edible giblets, while total non-edible parts were reduced $(\mathrm{P} \leq 0.05)$ in comparison with the control group.

Regarding relative organ lengths, the inclusion of graded concentrations of GSE caused a significant decrease of jejunum (up to 18\%; linear and quadratic effect), ileum (up to 19\%; linear effect) and ceca (up to $9 \%$; linear effect) at 21 days of age. However, at 42 days of age, an increase in the relative lengths of jejunum $(6 \%)$, ileum $(9 \%)$ and ceca $(14 \%)$ was only observed in birds fed the highest GSE concentration in the diet (Brenes et al., 2010).

\section{Blood parameters:}

The serum values of some blood constituents are shown in Table (4). The obtained values were within the normal range. Concentration of total cholesterol (TC), triglyceride (TG), low density lipoprotein $(\mathrm{LDL})$ were significantly $(\mathrm{P}<0.05)$ higher in control group (G1) than both treatments $(\mathrm{G} 2$ and $\mathrm{G} 3)$. While concentration of high density lipoprotein (HDL) was slightly $(\mathrm{P}<0.05)$ higher in group 2 than other 
groups glucose and creatinine concentration $(\mathrm{P}<0.05)$ decreased in both treatments $(\mathrm{G} 2$ and $\mathrm{G} 3)$ than control group $(\mathrm{G} 1)$.

Table (3): Effect of different oral grape seeds extract levels on carcass characteristics for growing rabbits.

\begin{tabular}{lccc}
\hline \multirow{2}{*}{ Item } & (G1) & \multicolumn{2}{c}{ Oral grape seeds extract level } \\
& Control & $(\mathrm{G} 2) 75 \mathrm{mg} / \mathrm{kg}$ & $(\mathrm{G} 3) 125 \mathrm{mg} / \mathrm{kg}$ \\
\hline Live weight, g & $1990.0 \pm 79.37$ & $1963.33 \pm 48.42$ & $2121.67 \pm 61.73$ \\
Weight after slaughter, g & $1933.33 \pm 74.96$ & $1915.0 \pm 50.33$ & $2058.33 \pm 58.33$ \\
Weight with abdominal, g & $1435.0 \pm 60.0$ & $1446.67 \pm 52.63$ & $1561.67 \pm 46.31$ \\
Giblets, g & $416.67 \pm 23.51$ & $378.33 \pm 19.22$ & $433.33 \pm 36.09$ \\
Empty, g & $896.67 \pm 54.87$ & $998.33 \pm 72.59$ & $1041.67 \pm 33.71$ \\
Head, g & $118.33 \pm 4.41$ & $120.0 \pm 2.89$ & $128.33 \pm 1.67$ \\
Lever, g & $64.47 \pm 2.24$ & $55.83 \pm 2.86$ & $66.433 \pm 2.19$ \\
Kidney, g & $15.73 \pm 2.18$ & $17.17 \pm 1.16$ & $17.90 \pm 2.56$ \\
Lung, g & $13.67 \pm 1.33$ & $19.37 \pm 2.04$ & $18.77 \pm 2.64$ \\
Bile, g & $1.30 \pm 0.26$ & $2.27 \pm 0.57$ & $1.17 \pm 0.09$ \\
Spleen, g & $1.13 \pm 0.19$ & $3.07 \pm 0.94$ & $4.77 \pm 1.96$ \\
Heart, g & $6.17 \pm 0.20$ & $8.07 \pm 1.20$ & $12.60 \pm 3.08$ \\
Shoulder fat, g & $3.23 \pm 0.42$ & $4.70 \pm 0.91$ & $2.47 \pm 1.44$ \\
Abdominal fat, g & $15.57 \pm 5.29$ & $16.0 \pm 3.28$ & $5.10 \pm 2.89$ \\
\hline
\end{tabular}

Table (4): Effect of different oral grape seeds extract levels on blood constituents for growing rabbits.

\begin{tabular}{lccc}
\hline \multirow{2}{*}{ Item } & (G1) & \multicolumn{2}{c}{ Oral grape seed extract level } \\
& Control & (G2) $75 \mathrm{mg} / \mathrm{kg}$ & (G3) $125 \mathrm{mg} / \mathrm{kg}$ \\
\hline ALT(IU/l) & $26.33 \pm 5.11$ & $30.33 \pm 5.39$ & $33.33 \pm 3.1$ \\
AST(IU/l) & $26.33 \pm 5.93^{\mathrm{a}}$ & $14.50 \pm 1.88^{\mathrm{b}}$ & $13.83 \pm 1.89^{\mathrm{b}}$ \\
Total Protein (g/dl) & $5.92 \pm 0.42$ & $5.48 \pm 0.22$ & $5.53 \pm 0.30$ \\
Albumin (g/dl) & $2.61 \pm 0.25$ & $2.87 \pm 0.104$ & $2.91 \pm 0.14$ \\
Globulin (g/dl) & $3.3 \pm 0.21$ & $2.62 \pm 0.22$ & $2.62 \pm 0.27$ \\
A/G ratio & $79.05 \pm 5.67$ & $114.44 \pm 12.06$ & $118.76 \pm 17.93$ \\
Creatinine (mg/dl) & $2.88 \pm 1.62$ & $1.32 \pm 0.07$ & $1.03 \pm 0.06$ \\
Total cholesterol (TC) (mg/dl) & $67.17 \pm 1.35^{\mathrm{a}}$ & $52.17 \pm 3.36^{\mathrm{b}}$ & $50.17 \pm 2.07^{\mathrm{b}}$ \\
Triglyceride (TG) & $34.17 \pm 2.34^{\mathrm{a}}$ & $20.83 \pm 2.88^{\mathrm{b}}$ & $23.83 \pm 4.5^{\mathrm{b}}$ \\
Glucose (mg/dl) & $33.33 \pm 5.89$ & $22.83 \pm 1.87$ & $22.17 \pm 2.01$ \\
HDL (mg/dl) & $34.0 \pm 5.16$ & $37.33 \pm 1.93$ & $35.83 \pm 1.14$ \\
LDL (mg/dl) & $27.17 \pm 5.28^{\mathrm{a}}$ & $12.0 \pm 1.51^{\mathrm{b}}$ & $10.67 \pm 0.604^{\mathrm{b}}$ \\
\hline
\end{tabular}

$a$ and $b-$-Means in the same row with different superscripts are significantly different $(P<0.05)$.

Some of studies has clearly revealed that polyphenols, mainly catechins, have antioxidative properties by the inhibition of low density lipoproteins (LDL) oxidation (Simonetti at al., 2002 and Shi et al., 2003). Furthermore, epicatechin, also protects endothelial cells against oxidized LDL by scavenging free radicals and maintaining nitric oxide synthase (Steffen et al., 2005).

Hassan, et al. (2016) found that plasma total protein, albumin and globulin were $(\mathrm{P} \leq 0.05)$ increased in New Zealand white rabbits fed GSE at 200 and $300 \mathrm{mg} / \mathrm{kg} \mathrm{LBW}$. In contrast, all supplementation levels of GSE $(\mathrm{P} \leq 0.05)$ reduced concentrations of total lipids, total cholesterol, triglycerides and lowdensity lipoproteins. Antioxidant enzymes of rabbits (superoxide dismutase, catalase, glutathione peroxidase, glutathione transferase) and total antioxidant capacity in blood were $(\mathrm{P} \leq 0.05)$ increased by fed GSE. However, malondialdehyde was $(\mathrm{P} \leq 0.05)$ reduced with increasing GSE levels.

Analysis of variance reveled that the activity of AST enzyme was significantly $(\mathrm{P}<0.05)$ lower in both treatments (G2 and G3) than control (G1) group (14.5, 13.83 and 26.33 IU/l), respectively. While the activity of ALT enzyme in opposite tendency, but not significant (Table 4). 
The antioxidant compounds present in grape seeds have been identified as phenolic acids (benzoic and hydroxycinnamic acids), stilbene derivatives, flavan-3-ols (catechin and epicatechin), flavonols (quercetin and myricetin), and anthocyanidins (Caillet et al., 2006).

Shi et al. (2003) reported that the antioxidant potential of grape seeds is twenty and fifty fold greater than vitamins $\mathrm{E}$ and $\mathrm{C}$, respectively, arising from increased levels of polyphenols proanthocyanidins and oligomers of flavan-3-ol units, especially catechin and epicatechin present in GSE (Yilmaz and Toledo, 2004).

\section{CONCLUSION}

These findings suggest that oral of grape seeds extract with level of $125 \mathrm{mg} / \mathrm{kg}$ lead to improvement growth performance, health status and decreasing lipid contents in the body of APRI rabbits.

\section{REFERENCES}

Allen, P. C. (2007). Anticoccidial effects of Xanthohumol. Avian Dis, 51: 21- 26.

Bakkali, F.; S. Averbeck; D. Averbeck and M. Idaomar (2008). Biological effects of essential oils. Food Chem Toxicol, 46: 446-475.

Benzie, I.F.F. (2003). Evolution of dietary antioxidants. Comparitive Biochemistyr and Physiology. Part A $136,113-126$.

Bodet, C.; F. Chandad and D. Grenier (2006). Anti-inflammatory activity of a high-molecular-weight cranberry fraction on macrophages stimulated by lipopolysaccharides from periodontopathogens. J. Dent. Res., 85: 235-239.

Brenes, A.; A. Viveros;I. Goñi3; C. Centeno; F. Saura-Calixto and I. Arija (2010). Effect of grape seed extract on growth performance, protein and polyphenol digestibilities, and antioxidant activity in chickens. Spanish Journal of Agricultural Research 8(2), 326-333.

Bucolo, G. and H. david (1973). Quantitative determination of serum triglycerides by the use of the enzymes . clin chem 19:475.

Caillet, S.; S. Salmieri and M. Lacroix (2006). Evaluation of free radical scavenging properties of commercial grape phenol extracts by a fast colorimetric method. Food Chem 95, 1-8.

Cos, P.; N. de Bruyne; S. Hermans; D. Apers; V. Berghe and A. J. Vlietink (2003). Proanthocyanidins in health care current and new trends. Curr. Med. Chem., 10: 1345-1359.

Doumas, B.T.; W.A. Watson and H.G. Biggs (1971). Albumin standards and the measurement of serum albumin with bromocresol green. Clin. Chim, 31: 87.

Duncan, B.D. (1955). Multiple range and multiple F test. Biometrics 11: 1-42.

Franchini, A.; F. Sirri; N. Tallarico; G. Minelli; N. Iaffaldano and A. Meluzzi (2002). Oxidative stability and sensory and functional properties of eggs from laying hens fed supranutritional doses of vitamins E and C. Poult. Sci. 81:1744-1750.

Friedewald, W.T.; R.R.I. Levy and D.S. Fredrickson (1972). Estimation of the concentration of lowdensity lipoprotein cholesterol in plasma without the use of preparative ultracentrifuge. Clin. Chem. 18: $499-502$.

Gonzalez-Paramas, A.M.; S. Esteban-Ruano; C. Santos-Buelga; S. Pascual- Teresa and J.C. RivasGonzalo (2004). Flavanol content and antioxidant activity in winery products. J. Agric. Food Chem., 52: 234- 238 .

Gornall, A.G.; C. J. Bardawill and M. M. David (1949). Determination of serum protein by means of the biuret reaction. J. Biol. Chim., 177:751.

Grashorn, M.A. (2007). Functionality of poultry meat. J. Appl. Poult Res., 16:99-106. 
Hassan, Fawzia A., K.M. Mahrose and M.M. Basyony (2016). Effects of grape seed extract as a natural antioxidant on growth performance, carcass characteristics and antioxidant status of rabbits during heat stress Journal Archives of Animal Nutrition, 70(2): 141-154.

Heim, K.E.; A.R. Tagliaferro and D.J. Bobilya (2002). Flavonoid antioxidants: Chemistry, metabolism andstructure-activity relationships. J. Nutr. Biochem., 3: 572-584.

Miguel, M.G. (2010). Antioxidant activity of medicinal and aromatic plants. A review. Flavour Fragr. J., 25: $291-312$.

Nanari, M.C.; A.K. Hewavitharana.; C. Beca and S. de Jong (2004). Effect of dietary tocopherols and tocotrienols on the antioxidant status and lipid stability of chicken. Meat Sci., 68:155-162.

Potman, T. and J. A. Stroes (1968). Lipids screening in clinical chimestry clinic chimica. Acta, 221: 569.

Puthpongsiriporn, U.; S.E. Scheideler.; J.L. Sell and M.M. Beck (2001). Effects of vitamin E and C supplementation on performance, in vitro lymphocyte proliferation, and antioxidant status of laying hens during heat stress. Poult. Sci., 80:1190-1200.

Reitman, S. and S. Frankel (1957). A colorimetric method for the determination of serum glutamate oxaloacetate and pyruvate transaminase. Am. J. Clin. Pathol., 28: 56-63.

Ruberto, G.; A. Renda; C. Daquino; V. Amico; C. Spatafora; C. Tringali and N. Tommasi (2007). Polyphenols constituents and antioxidant activity of grape pomace from five Sicilian red grape cultivars. Food Chem., 100:203-210.

Sahin, N.; F. Akdemir; C. Orhan; O. Kucuk; A. Hayirli and K. Sahin (2008). Lycopene enriched quail egg as functional food for humans. Food Res. Int. 41:295-300.

Saito, M.; H. Hosoyama; T. Ariga; S. Kataoka and N.Yamaji (1998). Antiulcer activity of grape seed extract and procyanidins. J. Agric. Food Chem., 46:1460-1464.

SAS (2004). SAS Institute Inc. SAS User's Guide, Statistics. Cary, NC.

Shi, J.; J.Yu; P.E. Pohorly and Y. Kakuda (2003). Polyphenolics in grape seeds- Biochemistry and functionality. J Med Food 6, 291-299.

Simonetti, P.; S. Ciappellano; C. Gardana; L. Bramati and P. Peitta (2002). Procyanidins from Vitis vinifera Seeds: In Vivo Effects on Oxidative Stress. J. Agric. Food Chem. American Chemical Society, 50: 6217-3221.

Steffen, Y.; T. Schewe and H. Sies (2005). Epicatechin protects endothelial cells against oxidized LDL and maintains NO synthase. Biochem. Biophys. Res. Commun., 331, 1277-1283.

Steven Lukefapor, W.D.; W.D. Hohenboken; P.R. Cheeke; N.M. Patton and W.H. Kennick (1981).Carcass and meat characteristics of Flemish giant and New Zealand white purebred and terminal cross rabbits. Journal of Applied Rabbit Research, 4 (3): 66-72.

Strain, J.J. and I.F.F. Benzie (1999). Diet and antioxidant defence. In: M. J. Sadler, J. J. Strain, B. Caballero (eds), Encyclopedia of Human Nutrition. Academic Press, London, pp. 95-106.

Tabacco, A. (1979). Quantitative enzymatic colorimetric determination in serum. Clin. Chem., 25: 336337.

Trinder, P. (1969). Determination of glucose in blood using glucose oxidase with an alternative oxygen acceptor. Ann. Clin. Biochim., $6: 24$.

Tuzcu, M.; N. Sahin; M. Karatepe; G. Cikim; U. Kilinc and K. Sahin (2008). Epigallocatechin-3-gallate supplementation can improve antioxidant status in stressed quail. Br. Poult. Sci., 49:643-648.

Wang, M.L.; X. Suo; J.H. Gu;W.W. Zhang; Q. Fang and X. Wang (2008). Influence of Grape seed Proanthocyanidin extract in broiler chickens: Effect on chicken coccidiosis and antioxidant status. Poult. Sci., 87: 2273-2280.

Yilmaz, Y. and R.T. Toledo (2004). Major flavonoids in grape seeds and skins: Antioxidant capacity of catechin, epicatechin, and gallic acid. J. Agric. Food Chem., 52: 255-260. 
تأثير تجريع مستخلص بذور العنب على أداء النمو وخصائص الذبيحة ومقاييس الام لذكور الأرانب النامية

عبد الخالق السيد عبد الخالق 1 ، حلمي قطب زغلول2 مختار زغلول عباس بدوى1

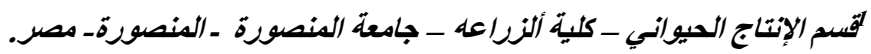

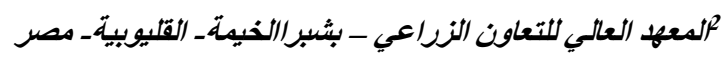

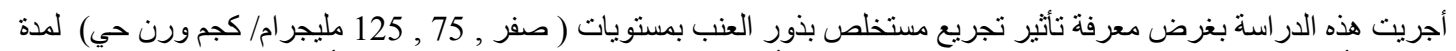

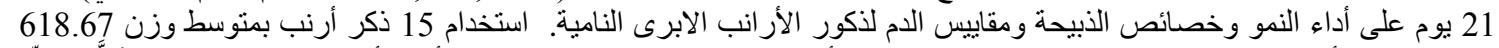

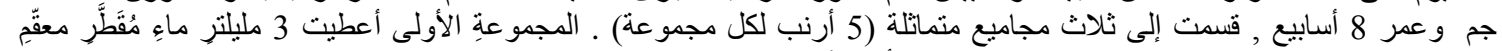

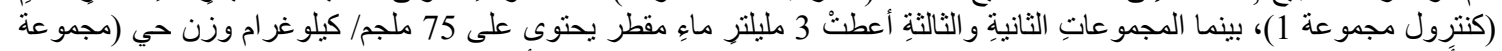

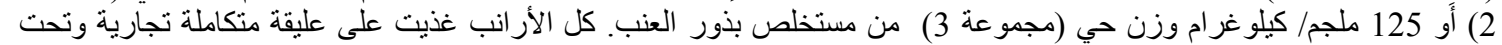

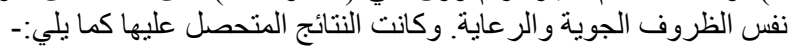

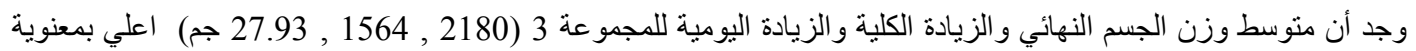
(P>0.05)

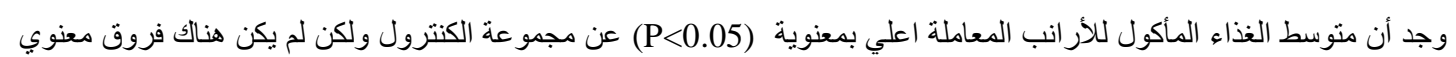
بين المعاملات.

أظهرت النتائج عدم معنوية تأثير المعاملة بمستخلص بذور العنب على متوسط التحويل الغذائي للأرانب (جم عليقه/جم زيادة في الوزن). و على أية حال الاتجاه يميل إلى النقص مع الأرانب المعاملة بمستوى 125 مليجرام مقارنة مع الأرانب المعاملة بمستوى لئل 75

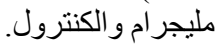

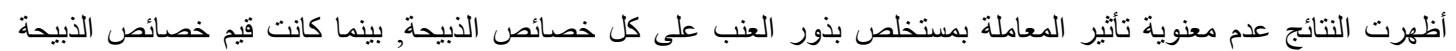

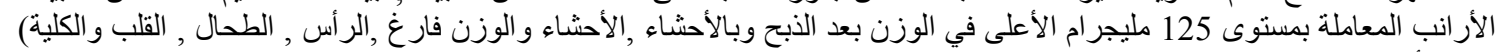
يليها الأر انب المعاملة بمستوى 75 مليجر ام يليها الكنترول.

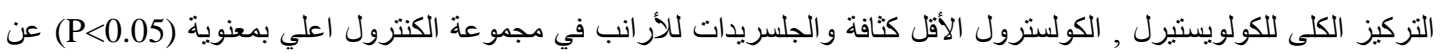

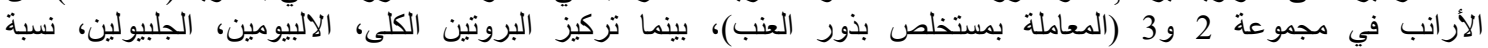

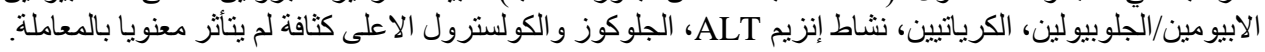

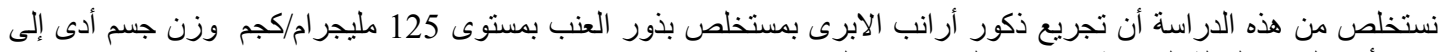
تحسن في أداء النمو و والحالة الصحية مع نقص اليبيدات في الجسم. 